\title{
Sorption of Sr-85 and Am-24I \\ from liquid radioactive wastes by alginate beads
}

Agata Oszczak, Leon Fuks

\begin{abstract}
The paper reports the adsorption of strontium(II) and americium(III) from aqueous solutions onto calcium alginate $(\mathrm{CaA})$, barium alginate $(\mathrm{BaA})$ and strontium alginate $(\mathrm{SrA})$ beads. Adsorption process was studied in batch experiments as a function of the initial $\mathrm{pH}$ of the solution and the contact time. All sorbents were examined by the termogravimetric analysis (TG). Laboratory obtained spherical beads of $\mathrm{CaA}$, BaA and SrA seem to be good metal sorbents from liquid radioactive wastes. A contact time of about $4 \mathrm{~h}$ and neutral pH of the initial aqueous solution have been proposed to be optimum conditions for Sr-85 and Am-241 removal from the contaminated solutions using alginate sorbents. Laboratory obtained beads of $\mathrm{CaA}, \mathrm{BaA}$ and $\mathrm{SrA}$ are characterized by the decontamination factor (DF) equal to $85 \%$ for $\mathrm{Sr}(\mathrm{II})$ and $90 \%$ for $\mathrm{Am}$ (III).
\end{abstract}

Key words: sorption $\bullet$ radionuclides $\bullet$ calcium alginate $\bullet$ barium alginate $\bullet$ strontium alginate

\author{
A. Oszczak ${ }^{\bowtie}$ L. Fuks \\ Institute of Nuclear Chemistry and Technology, \\ 16 Dorodna Str., 03-195 Warsaw, Poland, \\ Tel.: +48 22504 1252, \\ E-mail: a.oszczak@ichtj.waw.pl
}

Received: 18 June 2015

Accepted: 15 September 2015

\section{Introduction}

Environmental studies are confronted with a challenging task to develop appropriate low cost technologies for treatment of liquid wastes. Conventional methods for removing metals from aqueous solutions include chemical precipitation, chemical oxidation or reduction, ion exchange, filtration, electrochemical treatment, reverse osmosis, membrane technologies and evaporation recovery. However, these processes may occur to be ineffective or extremely expensive, especially when the metals in solution are in the concentration below $1 \mathrm{mg} \cdot \mathrm{L}^{-1}$ [1]. Another major disadvantage of the conventional treatment technologies is the production of great amounts of toxic sludge which disposal/treatment is a costly, non ecofriendly problem. Therefore, reduction of toxic and/ or radioactive metals to an environmentally safe level in a cost effective and environment-friendly way is of great importance. In a view of the above, natural sorbents of the biological origin have emerged as a prospective option $[2,3]$.

Biopolymers of alginic acid and its derivatives are got from two main sources: from various types of brown seaweed and from two forms of bacteria, Pseudomonas and Azotobacter. They show different structural and chemical properties depending on the season of their harvesting and on the growth conditions. However, all of these polymers form linear binary copolymers formed by $1-4$-linked $\beta$-Dmannuronic $(\mathrm{M})$ and $\alpha$-L-guluronic $(\mathrm{G})$ residues 


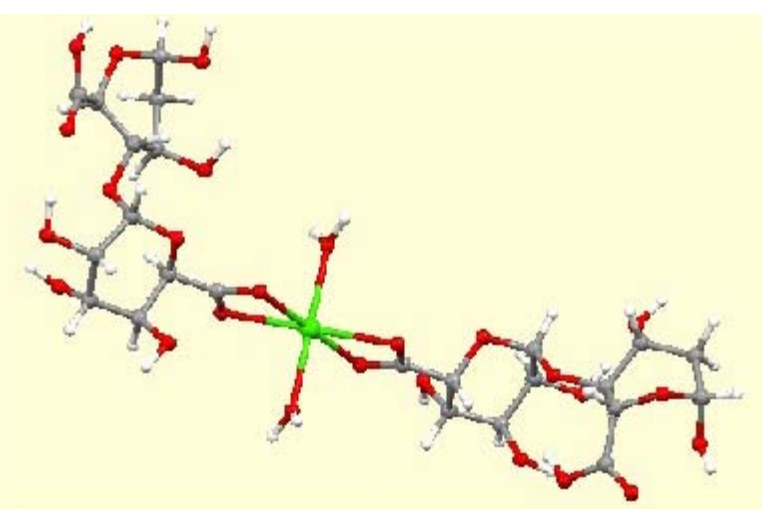

Fig. 1. Structure of the fragment of the alginate 'egg-box': MG-Ca-GM (energy minimization done by Spartan'08V1.2.0).

arranged with homopolymeric regions called as GG-, MM- and MG-blocks, respectively [4]. Alginates have numerous advantages, such as simple isolation technology, biodegradability, economic and environmental friendly characteristics [5]. Sodium salt of the alginic acid formed in the course of the isolation process may ionically cross-link (gelate) in the presence of multivalent cations. The most commonly used divalent cation for gelation is the divalent calcium ion, preferably complexed by the GG blocks of the neighbouring polymeric chains $[6,7]$. As a result, so-called egg box junctions are formed [8] (Fig. 1).

Radionuclides that were studied in the presented work were strontium-85 and americium-241. The former has been used as chemically identical to strontium-90, one of the most dangerous and difficult in detection of radionuclides. Strontium-90 is a radioactive by-product of fission reactions within nuclear reactors. About 3\% of the mass of spent nuclear fuel consists of fission products including Sr-90 [9]. It emits one beta particle and no gamma radiation. Strontium- 85 is generally used in the laboratory practice for determination of Sr-90 after the radiochemical separation. Due to its rather relatively high decay energy and long half-life of 28.8 years Sr-90 is classified as a high-level waste. The radionuclide deposits in bone and bone marrow, therefore exposure in the form of contaminated food and water is linked to bone cancer and leukemia [10]. It was found already that common freshwater green algae sequester strontium into insoluble crystals, offering a possible way to separate Sr-90 from less hazardous components of the nuclear waste [11].

There are numerous possible ways that radionuclide Am-241 could contaminate the environment. This ranges from nuclear reactors, nuclear explosions, and nuclear accidents, as well as from manufacturing products containing americium (such as smoke detectors). Americium-241 is also used for industrial gauging applications and in medical diagnostic devices. Because Am-241 has a long half-life (432.2 years), it will be present in the environment for a long time.

This paper presents the results of the studies on batch adsorption of both aforesaid radionuclides on three alginate sorbents. Namely, strontium- and barium alginates were compared with the commonly applied calcium alginate as potential sorbents for processing of the low level radioactive liquid wastes.

\section{Experimental}

\section{Chemicals and radionuclides}

Sodium alginate, as well as calcium-, barium- and strontium chlorides came from Sigma-Aldrich. The solutions were prepared in de-ionized water with electrical conductivity lower than $10 \mu \mathrm{S} \cdot \mathrm{cm}^{-1}$ at $25^{\circ} \mathrm{C}$. Carrier-free radionuclides of Sr-85 and Am-241 were supplied from the Radioisotope Centre POLATOM, National Centre for Nuclear Research (Świerk, Poland).

\section{Preparation of the sorbents}

Alginate beads were prepared by dropwise addition of $2 \%$ of viscous sodium alginate solution $(\mathrm{w} / \mathrm{v})$ to $0.5 \mathrm{~mol} \cdot \mathrm{L}^{-1}$ solution of $\mathrm{CaCl}_{2}, \mathrm{BaCl}_{2}$ or $\mathrm{SrCl}_{2}$, respectively, in room temperature. During the process, the water soluble sodium alginate was converted into insoluble metal-alginate spherical beads. After $30 \mathrm{~min}$ of stirring, the resulting gel beads were conditioned for another $30 \mathrm{~min}$, in the parent solution at room temperature. Following washing with de-ionized water to remove excess of the chlorides from the bead surface, the globules were collected by filtration and then placed in the bottle filled with the de-ionized water [12].

\section{Adsorption experiments}

Batch adsorption experiments of Sr(II) and Am(III) ions onto the alginate beads were carried out in the $10 \mathrm{~mL}$ polypropylene tubes. The initial concentration of strontium chloride spiked with $\mathrm{Sr}-85$ was $100 \mathrm{mg} \cdot \mathrm{L}^{-1}\left(1.14 \mathrm{mmol} \cdot \mathrm{L}^{-1} \mathrm{Sr}^{2+}\right.$ ions $)$. For the sorption studies of $\mathrm{Am}(\mathrm{III}), \mathrm{Eu}^{3+}$ was used as a carrier for Am-241 $\left(100 \mathrm{mg} \cdot \mathrm{L}^{-1}\right.$ i.e. $\left.0.658 \mathrm{mmol} \cdot \mathrm{L}^{-1}\right)$.

In all experiments, except these concerning studies of the dependence of sorption on the mass of the sorbent, the ratio of the alginate to liquid phase was $33 \mathrm{~g}$ to $1 \mathrm{~L}$ of the solution. Both phases were shaken together in the thermostatic shaker (type MKR 13; Merazet, Poznan, Poland) at room temperature. The equilibration period averaged 4 hours and the equilibrium $\mathrm{pH}$ was measured immediately prior to sampling using the $\mathrm{pH}$ meter Agilent Technologies (3200P Benchtop). The liquid phase was separated from the solid by centrifuging (6000 rpm, $20 \mathrm{~min})$. Activity concentrations of Sr-85 (half-life: 64.84 days; major gamma radiation: $514.0 \mathrm{keV}$ ) and Am-241 (half-life: 432.7 years; major radiation: alpha - 5.4 MeV; gamma - 59.5 keV) in the initial and equilibrium liquid phases were determined radiometrically using a PerkinElmer 2480 Wizard2 ${ }^{\circledR}$ automatic gamma counter. In each experiment the final result was calculated as mean value from trip- 
licate independent samples and all radiometric measurements of each sample were repeated three times.

Sorption properties of the sorbent were presented in terms of the decontamination factors (DF), i.e. the ratio of specific activities before $\left(\mathrm{A}_{0}\right)$ and after sorption $\left(A_{\text {eq }}\right)$, expressed in the percent [13]

$$
\mathrm{DF}=\frac{\mathrm{A}_{\mathrm{eq}}}{\mathrm{A}_{0}} \times 100 \%
$$

where $\mathrm{A}_{0}$ and $\mathrm{A}_{\mathrm{eq}}$ are expressed as [cps. $\mathrm{mL}^{-1}$ ].

In the next step, desorption studies of $\mathrm{Sr}$ (II) and Am(III) from the sorbent previously loaded with the radionuclides were performed. The sorbent (33 g) were four times consecutively treated with $1 \mathrm{~L}$ of de-ionized water and shaken for 3 hours. Each portion of water was separated from the beads by centrifugation. Radioactivities of the aqueous and the solid phase were measured by gamma spectrometry for determination of the concentrations of $\mathrm{Sr}$ (II) and Am(III) released into the aqueous phase and remaining in the solid one.
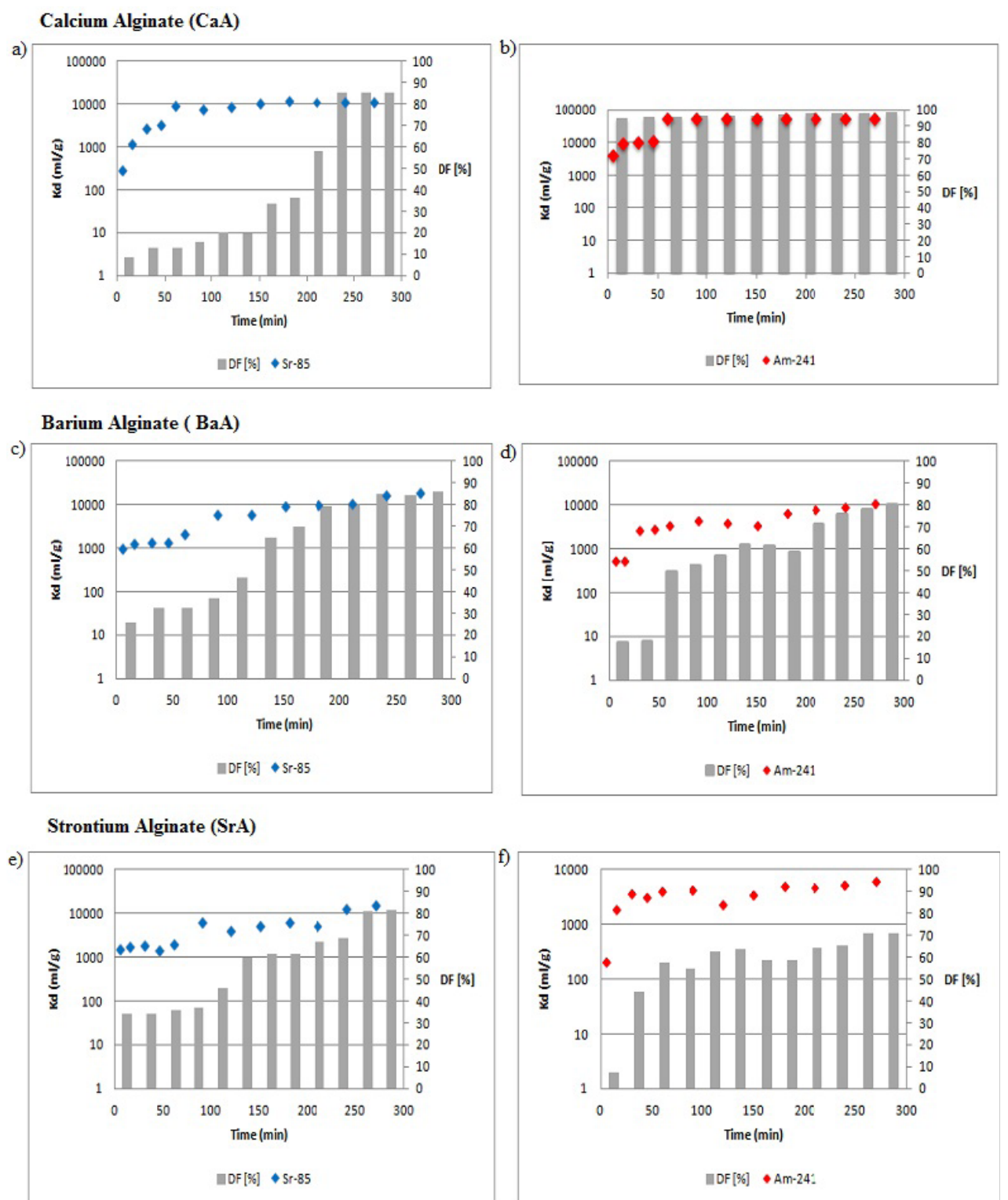

Fig. 2. Influence of contact time on the $\mathrm{K}_{\mathrm{d}}$ and DF of solutions containing strontium(II) and americium(III); (a-f) $23^{\circ} \mathrm{C}, \mathrm{pH}$ 5: open square box calcium alginate, barium alginate and strontium alginate. 


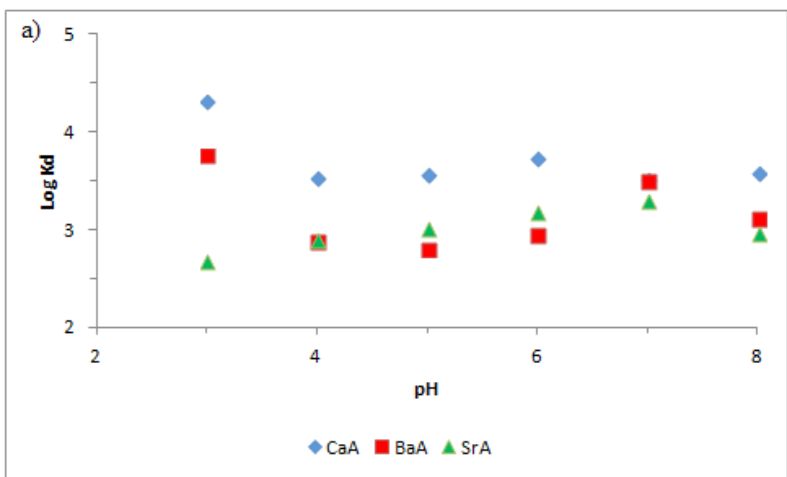

Fig. 3. Effect of initial $\mathrm{pH}$ on the sorption of carier-free $\mathrm{Sr}(\mathrm{I})$

reached usually within $1 \mathrm{~h}$. After this time distribution coefficient is independent from the contact time of equilibrated phases. In detail, the decontamination factor at $\mathrm{pH}$ of 5 and a temperature of $25^{\circ} \mathrm{C}$ after $4 \mathrm{~h}$ is equal to $87 \pm 0.04 \%$ for $\mathrm{Sr}(\mathrm{II})$ and $98 \pm 0.03 \%$ for $\mathrm{Am}$ (III) in the case of CaA, $84 \pm 0.23 \%$ for $\mathrm{Sr}$ (II) and $78 \pm 0.06 \%$ for $\mathrm{Am}$ (III) in the case of $\mathrm{BaA}$, and $81 \pm 0.21 \%$ for $\mathrm{Sr}$ (II) and $70 \pm 0.15 \%$ for $\mathrm{Am}$ (III) in the case of SrA. Based on these results, solid sorbents were chosen to contact with the liquid phase for $4 \mathrm{~h}$ in further experiments.

Each drawing of Fig. 2(a-f) presents value of DF (right axis) and $\mathrm{K}_{\mathrm{d}}$ (left axis) which was defined as:

$$
\mathrm{K}_{\mathrm{d}}=\frac{\mathrm{A}_{0}-\mathrm{A}_{\mathrm{eq}}}{\mathrm{A}_{0}} \times \frac{V}{m}
$$

where $\mathrm{A}_{0}$ and $\mathrm{A}_{\text {eq }}$ are expressed as [cps $\left.\cdot \mathrm{mL}^{-1}\right], V$ is the volume of the aqueous phase [mL], $m$ is the weight of the alginate beads [g].

\section{Effect of initial $\mathrm{pH}$}

The initial acidity of the solution is one of the decisive factors determining the efficiency of metal uptake from aqueous solutions. It affects both surface of the sorbent as well as the speciation of the metal ion in solution which additionally, depends on the concentration of the metal.

The results obtained for strontium(II) and americium(III) sorption for the initial $\mathrm{pH}$ ranging from 3 to 8 are illustrated in Fig. 3. Total $\mathrm{Sr}$ and $\mathrm{Am}$ concentration was $10^{-6} \mathrm{~mol} \cdot \mathrm{L}^{-1}$ and $3.2 \cdot 10^{-9} \mathrm{~mol} \cdot \mathrm{L}^{-1}$, respectively.

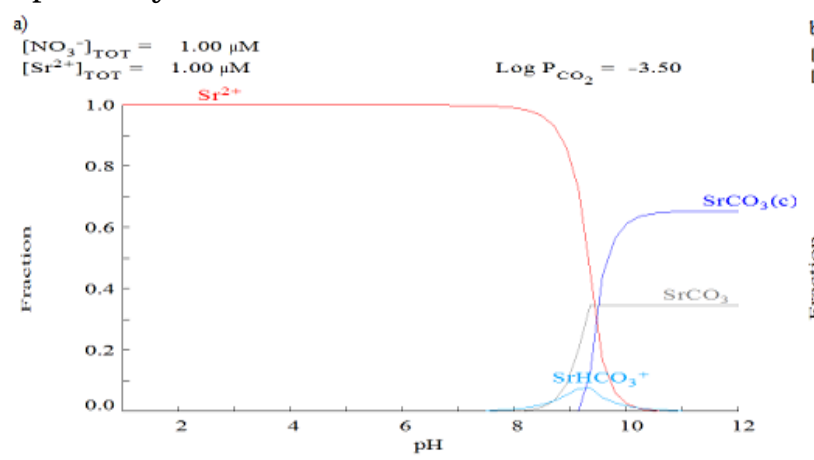

Fig. 4. Speciation of strontium and americium in aqueous solutions, calculated by means of Hydra-Medusa software. Total Sr and nitrate concentration were $10^{-6} \mathrm{~mol} \cdot \mathrm{L}^{-1}$ each, total Am concentration was $3.2 \cdot 10^{-9} \mathrm{~mol} \cdot \mathrm{L}^{-1}$ and nitrate concentration $-9.6 \cdot 10^{-9} \mathrm{~mol} \cdot \mathrm{L}^{-1}$.

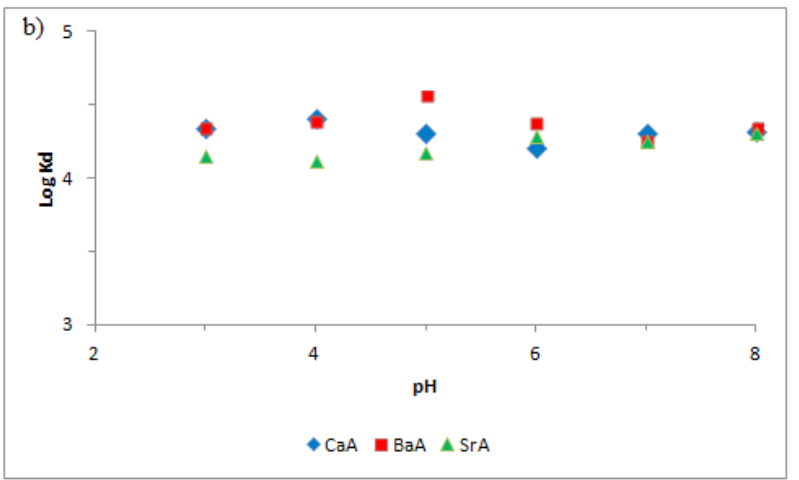

(a) and $\mathrm{Am}(\mathrm{III})(\mathrm{b}) ; 23^{\circ} \mathrm{C}, t=5 \mathrm{~h}$, on the studied sorbents.

The calculations by Hydra-Medusa software (Fig. 4) show in acidic conditions the only present species are $\mathrm{Sr}(\mathrm{II})$ and/or $\mathrm{Am}(\mathrm{III})$. However, at $\mathrm{pH}$ 6.5-7, monovalent $\mathrm{Sr}\left(\mathrm{HCO}_{3}\right)^{+}, \mathrm{Am}\left(\mathrm{CO}_{3}\right)^{+}$and divalent $\mathrm{Am}(\mathrm{OH})^{2+}$ species may be found in significant amounts. The ionization state of functional groups was highly dependent on $\mathrm{pH}$ and should be studied. It is known from the literature that carboxyl groups present in the biomass play an important role in metal sequestration, being responsible for a major fraction of metal immobilization [14]. The $\mathrm{pK}_{\mathrm{a}}$ value of the carboxylic group existing in biomass varies from about 2 to 4.7 [15], therefore at $\mathrm{pH}$ around 4.5 , the extent of its dissociation should roughly approach $50 \%$. Generally, at $\mathrm{pH} \approx 1.5$ the majority of other groups are protonated, inducing positive or neutral charge, and hence their interactions with positively charged strontium and americium species are not favoured by electrostatic forces. With increasing $\mathrm{pH}$, the negative charge density on the functional groups increases which favours their interaction with the positively charged $\mathrm{Sr}(\mathrm{II})$ and Am(III) species, thus their biosorption increases.

\section{Evaluation of the thermal stability of sorbents}

The thermogravimetric (TGA) data (Fig. 5) for all studied sorbents showed a sharp reduction in weight at the temperatures just above $100^{\circ} \mathrm{C}$. However, thermal decomposition of spherical $\mathrm{CaA}$ beads occurs at much lower temperatures than of the as-received sorbents. Weight loss of the samples up to $37 \%$ was detected at $167^{\circ} \mathrm{C}$ for the $\mathrm{CaA}$ beads, and at $560^{\circ} \mathrm{C}$

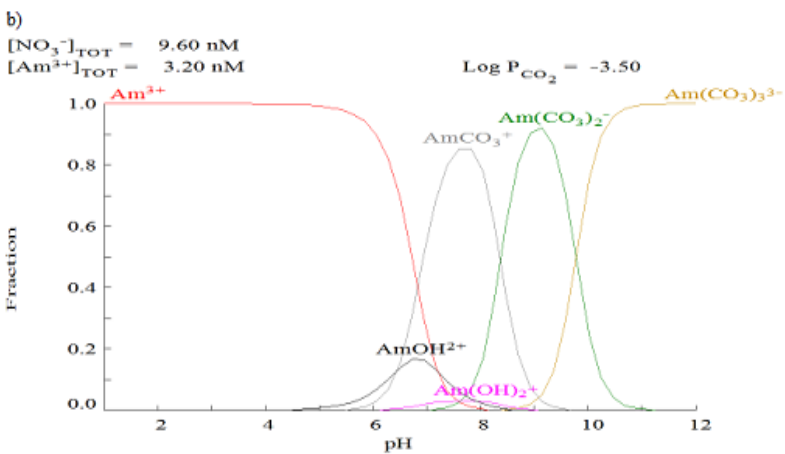




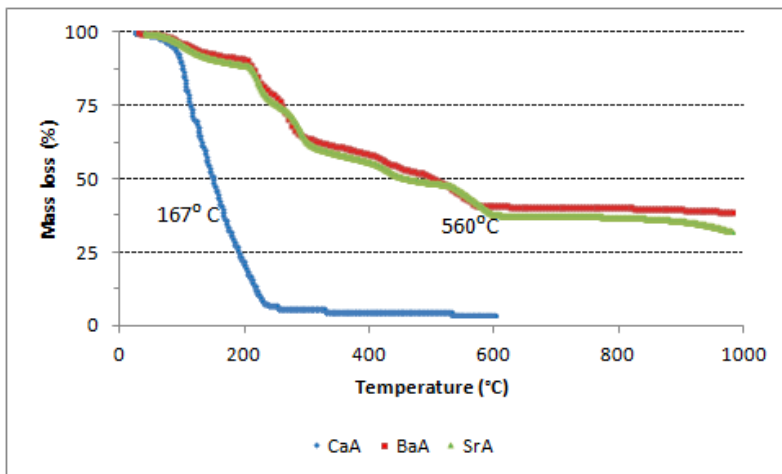

Fig. 5. TGA curves of the sorbents studied.

for the $\mathrm{BaA}$, and $\mathrm{SrA}$ respectively. The total weight loss curves for both as-received sorbents show three sharply decreasing regions, which may be attributed to the liberation of the adsorbed water and decomposition of the sorbents [16]. Stable forms of the studied materials (respective carbonate compounds) appeared at the temperatures of $220^{\circ} \mathrm{C}(\mathrm{CaA})$ and $560^{\circ} \mathrm{C}$ (BaA and $\left.\mathrm{SrA}\right)$. This means that the energy necessary to reduce the mass of the solid wastes, may by relatively low, which decreases the cost of the process.

\section{Conclusions}

Alginate beads, $\mathrm{CaA}, \mathrm{BaA}$ and $\mathrm{SrA}$, seem to be effective sorbents of certain radionuclides from liquid radioactive wastes. The beads revealed high decontamination factors (DF): $85 \%$ for $\mathrm{Sr}$ (II) and 90\% for Am(III). The contact time of about $4 \mathrm{~h}$ and a neutral initial $\mathrm{pH}$ seem to be the optimum conditions for Sr-85 and Am-241 to be removed from contaminated solutions, using $\mathrm{CaA}, \mathrm{BaA}$ and $\mathrm{SrA}$ beads. The TGA properties of this material show that pretreatment of the radioactive wastes containing strontium and americium immobilized on the spherical $\mathrm{CaA}$ beads require less energy input than on the $\mathrm{BaA}$ and $\mathrm{SrA}$ sorbents.

Acknowledgments. The research has been financed from the National Centre for Research and Development (Poland) through the "Strategic program technologies supporting development of safe nuclear power engineering", task 4 "Development of spent nuclear fuel and radioactive waste management techniques and technologies". We thank Dr Dariusz Sternik (Maria Curie-Skłodowska University) for performing the thermogravimetric analyses.

\section{References}

1. Nourbakhsh, M., Sag, Y., Ozer, D., Aksu, Z., Katsal, T., \& Calgar, A. (1994). A comparative study of various biosorbents for removal of chromium(VI) ions from industrial wastewater. Process Biochem., 29, 1-5.

2. Volesky, B. (Ed.).(1990). Biosorption of heavy metals (pp. 3-6). Boca Raton: CRC Press.

3. Hawieńczyk, M., Bystrzejewska-Piotrowska, G., Kowalska, J., \& Asztemborska, M. (2005). Platinum bioaccumulation by mustard plants (Sinapis alba L.). Nukleonika, 50(Suppl. 1), S59-S61.

4. Giavasis, I., \& Biliaderis, C. G. (2007). Microbial polysaccharides. In Functional food carbohydrates (pp. 174-176). New York: CRC Press.

5. Se-Know, K. (2015). Handbook of marine biotechnology. Dordrecht: Springer.

6. Khandai, M., Chakraborty, S., Sharma, A., Pattnaik, S., Patra, C. N., Dinda, S. C., \& Sen, K. K. (2010). Preparation and evaluation of algino-sericin microspheres: an approach for sustained drug delivery. $J$. Adv. Pharm. Res., 1, 48-60.

7. Donati, I., \& Paoletti, S. (2009). Material properties of alginates. In B. H. A. Rehm (Ed.), Alginates: Biology and applications (pp. 1-53). Berlin-Heidelberg: Springer.

8. Li, L., Fang, Y., Vreeker, R., Appelqvist, I., \& Mendes, E. (2007). Reexamining the egg-box model in calcium-alginate gels with X-ray diffraction. Biomacromolecules, 8, 464-468.

9. World Nuclear Association. (2011). WNA Radioactive Waste Management. Retrieved April 29, 2011, from http://www.tinyurl.com/448n8k7.

10. U.S. Environmental Protection Agency. (2011). EPA. Strontium. Retrieved April 29, 2011, from http:// www.tinyurl.com/ye5y6g4EPA.

11. Krejci, M. R., Finney, L., Vogt, S., \& Joester, D. (2011). Selective sequestration of strontium in desmid green algae by biogenic co-precipitation with barite. ChemSusChem, 4, 470-473.

12. Fuks, L., Oszczak, A., Gniazdowska, E., \& Sternik, D. (2015). Calcium alginate and chitosan as potential sorbents for strontium radionuclide. J. Radioanal. Nucl. Chem., 304, 15-20.

13. European Nuclear Society. (2013). Decontamination factor. Retrieved March 17, 2013, from http://www. euronuclear.org/info/encyclopedia/d/decontaminationfactor.html

14. Filipiuk, D., Fuks, L., \& Majdan, M. (2005). Transition metal complexes with uronic acids. J. Mol. Struct., 744/747, 705-709.

15. Wang, J., \& Chen, C. (2009). Biosorbents for heavy metals removal and their future. Biotechnol. Adv., 27, 195-226.

16. Soares, J. P., Santos, J. E., Chierice, G. O., \& Cavalheiro, E. T. G. (2004). Thermal behavior of alginic acid and its sodium salt. Ecl. Quim., 29, 57-63. 